Article

\title{
Sustainable Assessment of Alternative Sites for the Construction of a Waste Incineration Plant by Applying WASPAS Method with Single-Valued Neutrosophic Set
}

\author{
Edmundas Kazimieras Zavadskas ${ }^{1, *}$, Romualdas Baušys ${ }^{2,+}$ and Marius Lazauskas ${ }^{1,+}$ \\ Received: 24 September 2015; Accepted: 23 November 2015; Published: 1 December 2015 \\ Academic Editors: Fausto Cavallaro and Marc A. Rosen \\ 1 Research Institute of Smart Building Technologies, Vilnius Gediminas Technical University Saulètekio ave. 11, \\ Vilnius LT-10223, Lithuania; marius.lazauskas@gmail.com \\ 2 Department of Graphical Systems, Vilnius Gediminas Technical University Saulètekio ave. 11, \\ Vilnius LT-10223, Lithuania; romualdas.bausys@vgtu.lt \\ * Correspondence: edmundas.zavadskas@vgtu.lt; Tel.: +3-705-274-4910 \\ + These authors contributed equally to this work.
}

\begin{abstract}
The principles of sustainability have become particularly important in the construction, real estate maintenance sector, and all areas of life in recent years. The one of the major problem of urban territories that domestic and construction waste of generated products cannot be removed automatically. The above necessity induces the demand of systems and technologies for waste life cycle and proper disposal development. Siting of the waste incineration plant is a complex process, which includes all factors of sustainability principles. The selection of the construction area is a complex problem due to the existence of different tangible and intangible factors and the multiple alternatives available. Multicriteria decision-making methods (MCDM) present powerful and flexible techniques for the solution of many sustainability problems. In this paper, we propose a new extension of WASPAS method, namely WASPAS-SVNS. This extension is realized in the framework of the single-valued neutrosophic set that enables to represent and model the indeterminacy explicitly and the functions of the truth-membership, the indeterminacy-membership and the falsity-membership are not related to each other. The paper deals with the solution of the waste incineration plant siting problem due to the requirements of sustainability factors.
\end{abstract}

Keywords: sustainability assessment; waste incineration; MCDM; WASPAS-SVNS; neutrosophic set

\section{Introduction}

Recently, European Commission announced a new strategy concerning circular economic systems, which would enable improved resource productivity by using the products repeatedly without turning them into waste [1]. This circular economic strategy will require the transition to new business and the social management models.

During the last decade the application of the sustainability principles has become an essential requirement of the modern urban infrastructure projects [2-6]. Turning the waste into resources is one of the elements within the framework of the circular economic system. Thus, particular attention must be directed to innovation in recycling, the repetitive use of the products, and other aspects of the waste management. The holistic approach to solve these problems is called integrated solid waste management (ISWM). This strategy incorporates all aspects of waste management, such as prevention, recycling, composting, and disposal. We can distinguish the following options in waste management: source reduction, recycling, composting, waste to energy, and landfilling waste. 
Applying ISWM, the most effective waste management actions can be chosen taking into account local urban, social and environmental conditions [7,8]. In Lithuanian cities municipal waste management is an issue of primary concern due to the environmental hazards of great significance. All of these processes must be balanced from a sustainable point of view. Solid waste management is of the utmost importance, especially in the cities, where this key service of city management can provide the framework, by which public health and development of a city can be achieved.

Nowadays, waste management has reached a high technological level and numerous elements, such as sophisticated collection systems, together with efficient separation procedures, allow the achievement of a high degree of recovery and recycling. These measures enable a large amount of municipal solid waste to be treated, applying waste to energy technologies [9]. Margallo et al. [10] studied the effects of the environmental sustainability assessment methodology on the complexity of life cycle assessment and the possibilities to apply it in the decision-making process.

The numerous studies concerning efficient integrated solid waste management have been performed in the cases the high-income countries and only a few analyses have been directed toware the cases of developing countries. The proposed frameworks of sustainable waste management enveloped the different criteria describing waste prevention activities, zero waste management systems, and 3R (reduce, reuse, recycle) policies that enabled making the conversion from waste management to resource management, seeking an acknowledgment with European Union requirements [11]. Currently, the strategy of integrated sustainable waste management outlines the paradigm for the assessment of the sustainability of waste management alliances. The essence of this strategy consists of the necessity to examine not only technical or financial-economic aspects, but also environmental, institutional, and other issues that have an impact on sustainability of waste management [12].

The waste incineration plant siting process involves different environmental, social, and political criteria, which are derived applying local requirements. The framework for the choice of an appropriate, wholesome strategy for contaminated sites can be considered a multi-criteria decision-making problem which includes technical, environmental, safety, stakeholder preferences, and the other criteria [13]. All stakeholders need to be dedicated, engaged, and collaborate to identify possible compromises of waste generation and consequently intervene to minimize the waste amounts [14]. The different aspects of the waste management problems had been considered applying the general framework of multi-criteria decision-making [15-17].

Multi-criteria decision-making, in general, establishes alternatives among different options by making reference to a set of objectives that the decision-making topic has already identified. MCDM puts an accent on the assessment of the decision-making topic, on contributing criteria, on determining relative weights and, to an extent, on calculating the performance of each option against each satisfaction criterion. Decision-making in this particular problem of the sustainability assessment of waste incineration plant construction site selection consists of evaluating alternatives with respect to multiple conflicting criteria and selecting the "best" alternative considering the results obtained by evaluation approach. There have been proposed a huge variety of multi-criteria decision-making methods to solve such types of problems [18-22]. MCDM methods are of the utmost significance since they can evaluate different alternatives not only taking into account the data of various criteria, but also the format of the presentation, such as crisp, fuzzy, and others.

Different sustainability problems have been solved applying the framework of the multi-criteria decision-making. The assessment of the affordability of different locations, applying criteria reflecting various aspects of the sustainability was performed by the COPRAS method of multi-criteria decision-making in [23]. The problem of the green supplier of the thermal power equipment for power plants in China was considered and solved by the TOPSIS approach under a triangular fuzzy number environment [24]. A sustainability assessment of the energy systems by the application of MCDM strategy, namely the SWARA approach, was presented in [25]. Modern fuzzy approaches have been implemented to solve investment strategies in the private sector of Iran [26] and to perform 
environmental impact assessment (EIA) processes for evaluation of the possible impact of mine development and operations on the environment, including the natural, social, and economic aspects was presented in [27].

There are a lot of problems and it is very difficult in the real world to extract precise data referring to the estimation factors since all human selections are inclined to a degree of uncertainty. During the last decade the various formulations of the fuzzy sets have been developed and different MCDM problems have been solved [28-31]. However, they usually cannot take into account all patterns of uncertainties that are usually met in the models of the real world problems.

In recent years different approaches are proposed to extend the crisp MCDM methods into a fuzzy environment in order to deal with uncertain information [20,27-30].

Recently, new neutrosophic sets have been proposed by Smarandache [32] and these neutrosophic sets allow dealing with "knowledge of neutral thought" and this "neutral" component distinguishes this set from the other approaches that model uncertain phenomena of information. In fact, the neutrosophic sets are a generalization of the "fuzzy" and "intuitionistic fuzzy" sets. Nowadays the research proposes some applications of the neutrosophic sets for the solution multi-criteria decision-making problems. Recently, Peng et al. [33] have studied the computational aspects, applying single-valued neutrosophic sets in multi-criteria decision-making approaches. Zhang and Wu [34] developed a novel method for the solution of the single-valued neutrosophic multi-criteria decision-making problems under the assumption of the incomplete weight information.

This paper focuses on waste incineration plant construction site planning taking into account the ecological, technological, and urban aspects. The article aims to show how the multi-criteria decision methods (MCDM) can be applied to solve practical problem of the siting of the waste incineration plant, including not only technical, but also sustainability requirements. The applicability and usefulness of a joint method as a combination of two criteria of optimality, namely WSM (Weighted Sum Model) and WPM (Weighted Product Model), namely a Weighted Aggregated Sum Product Assessment (WASPAS) [28], is explored solving siting waste incineration plant construction sites. For the solution we proposed a new extension of the original WASPAS method, namely WASPAS-SVNS, which is governed by a single-valued neutrosophic set.

\section{Waste Management Strategies}

Continuous population growth affects the increase in the consumption of goods and services. However, the increase in the consumption has positive, as well as negative, outcomes. The increase in demand necessitates more energy, firstly, for the production of certain raw materials required for the manufacture of goods and, then, for the production, packaging, and logistics of manufactured goods. Indirect investments are made into the marketing of products, which also requires certain material resources. There is a persisting global issue regarding the re-use or utilization of no longer required materials, i.e., waste. Not only does this issue concern regions that house the largest economies but also small states, such as Lithuania. The situation on the Lithuanian market of construction and municipal waste seems grave. Regional municipal waste landfills are overflowing due to the lack of infrastructure for waste sorting and full re-use of all types of non-hazardous waste. At the end of 2014, the overflowing regional landfill of Vilnius County resulted in problems with the collection of construction waste. These problems were unearthed because of the lack of a system for sorting, re-use, and final utilization of waste. A similar situation prevails on the global scale, which necessitates a greater focus on the improvement of waste management, re-use, and utilization systems, strategic planning, and the development of the model for a sustainable system.

Municipal waste management systems must be organized to ensure that cities, townships, and villages have (a) means for the collection and removal of waste; (b) means for waste sorting at the place of its origin; (c) means for separate collection of different municipal waste flows, such as construction and demolition wastes from households, bulky waste (furniture, etc.), discarded 
electrical and electronic equipment, end-of-life tires, etc.; and (d) means for separate collection of hazardous wastes from households (except for batteries and accumulators).

According to the analysis of possible waste management strategies, all new waste management facilities must be constructed as an inseparable part of the already-functioning regional waste management system and the improvement of this system must consider principles of sustainable development. Selection of sites for waste management and incineration facilities depends on a number of important factors, including the most advanced engineering infrastructure required for such facilities and available in the territory of cities, as well as close proximity to the consumer of energy, which is planned to be generated (heat and electricity).

In 2000, 130 thousand tons of biodegradable waste (approx. 50\% of the total quantity of all municipal and similar wastes) was disposed of in Vilnius County landfills. Considering the targets set out in the Council Directive 99/31/EC on the landfill of waste, no more than 97.5 tons of biodegradable waste had to be disposed of in the regional landfill of Vilnius County since 2010, no more than 65 thousand tons-since 2013, and no more than 45 thousand tons-since 2020. The real waste disposal situation was presented in [35].

Considering the situation of the city of Vilnius and based on the report of the on the report on the Economic Analysis of Options for Managing Biodegradable Municipal Waste [36], there are four possible scenarios for further waste management (Table 1).

The first alternative anticipates the maximum separate collection of secondary raw materials (and packaging waste), garden wastes, and biodegradable wastes (including the production of biogas and its preparation), a separate treatment of such wastes (ensuring a possibly higher quality of the resultant product), and the financial assistance for the introduction and operation of home composting sites (Vilnius County has approx. 73,000 private homes). To maximize the recovered amounts of secondary raw materials and packaging waste fit for recycling from the municipal waste flows, this alternative envisages a waste sorting plant, which would also ensure the qualitative composition of incinerated wastes. Only sorted wastes, which are unsuitable for recycling, are incinerated. The produced electric and heat energy is sold to compensate some of the waste management costs.

The second and third alternatives generate significant waste flows to the landfill. The anticipated tax for the environmental pollution by waste would increase the general waste management costs by approx. $25 \%$. Post 2020, these alternatives will require systematic changes and additional investments.

Table 1. Options for the waste management strategy of the city of Vilnius.

\begin{tabular}{|c|c|c|c|c|}
\hline Technological Processes & I & II & III & IV \\
\hline Secondary collection of secondary raw materials & + & + & + & + \\
\hline Secondary collection and composting of garden wastes & + & + & + & + \\
\hline Home composting & + & + & - & + \\
\hline Mechanical biological treatment & - & - & + & + \\
\hline $\begin{array}{l}\text { Collection and separate treatment of a } \\
\text { biodegradable fraction }\end{array}$ & + & + & - & + \\
\hline $\begin{array}{c}\text { Separation of a biodegradable fraction and } \\
\text { production of biogas }\end{array}$ & - & - & + & - \\
\hline $\begin{array}{c}\text { Mechanical waste sorting plant (production of } \\
\text { secondary raw materials) }\end{array}$ & + & + & + & + \\
\hline Preparation of waste for incineration and incineration & + & - & - & + \\
\hline Disposal of waste by landfill & + & + & + & + \\
\hline
\end{tabular}

The fourth alternative does not provide a separate collection of biodegradable waste. However, it emphasises the centralized treatment of collected mixed municipal waste, the use of technological means to separate secondary raw materials, and packaging waste, which are suitable for recycling, and shredding the remaining waste, which is then sent to a biological drying facility, where wastes are aerated and dried. This results in smaller amounts ( $20 \%$ less) of waste, which has a greater thermal value ( $20 \%$ more). The waste becomes stabilized and can be warehoused for a longer period prior to 
incineration (the level of moisture of such waste is 10\%-20\% depending on the duration of treatment). This alternative provides incineration of fuel produced from waste in a waste incineration facility [37].

Assessment of these alternatives from the point of view of sustainable development results in the choice of the strategy that brings the most value to the waste management system, ensuring the liquidity of waste and the production of electric and heat energy, i.e., choosing the waste turnover system with an incineration option. It is this strategy, which serves as the basis for the solution of the problem that seeks to identify the most appropriate site for the project implementation in the city of Vilnius, considering opinions of most stakeholder groups.

\section{Possible Alternatives}

Incineration plants are assessed based on a wide range of criteria justified by requirements set for the environmental protection and ecology as well as by social attitudes, economic benefit, the need for financing and planned return, architectural cultural norms of the city, and technological capabilities for project implementation [30]. Solving the problem concerning the selection of the construction site for a waste incineration plant, the authors chose seven potential alternatives for the project implementation. To identify a suitable site for a waste incineration plant, it is important to consider the requirements of all stakeholder groups and find an alternative solution. Therefore, this problem is addressed by assessing engineering, social, economic and environmental factors (Table 2).

Engineering factors $\left(x_{1}-x_{3}\right)$ cover a part of investments required for the project development. Residential, office, industrial, and public sector buildings cannot function without engineering communications. The analysis of industrial structures in general, and heat and electric power production facilities, in particular, revealed specific requirements, such as the need to be connected to electric power transmission grid or other systems to supply produced heat or power to end-users. Such supply also requires pipelines and electric lines. Additionally, local surface runoff cannot be directed to the city sewage as rainwater would mix with wastewater, and the mixture would put a strain on wastewater treatment facilities of the city.

The distance from a waste sorting base to a waste incineration plant $\left(x_{2}\right)$ determines solutions to logistics problems. Clearly, a waste sorting base must be located further away from densely-populated territories as the waste sorting technology also includes waste warehousing, which often involves open-air storage. Such facilities are open to environmental processes and usually emit odors to surrounding territories. Certainly, open-air warehousing of waste also results in the visual pollution of residential areas.

Table 2. Factors of alternative assessment.

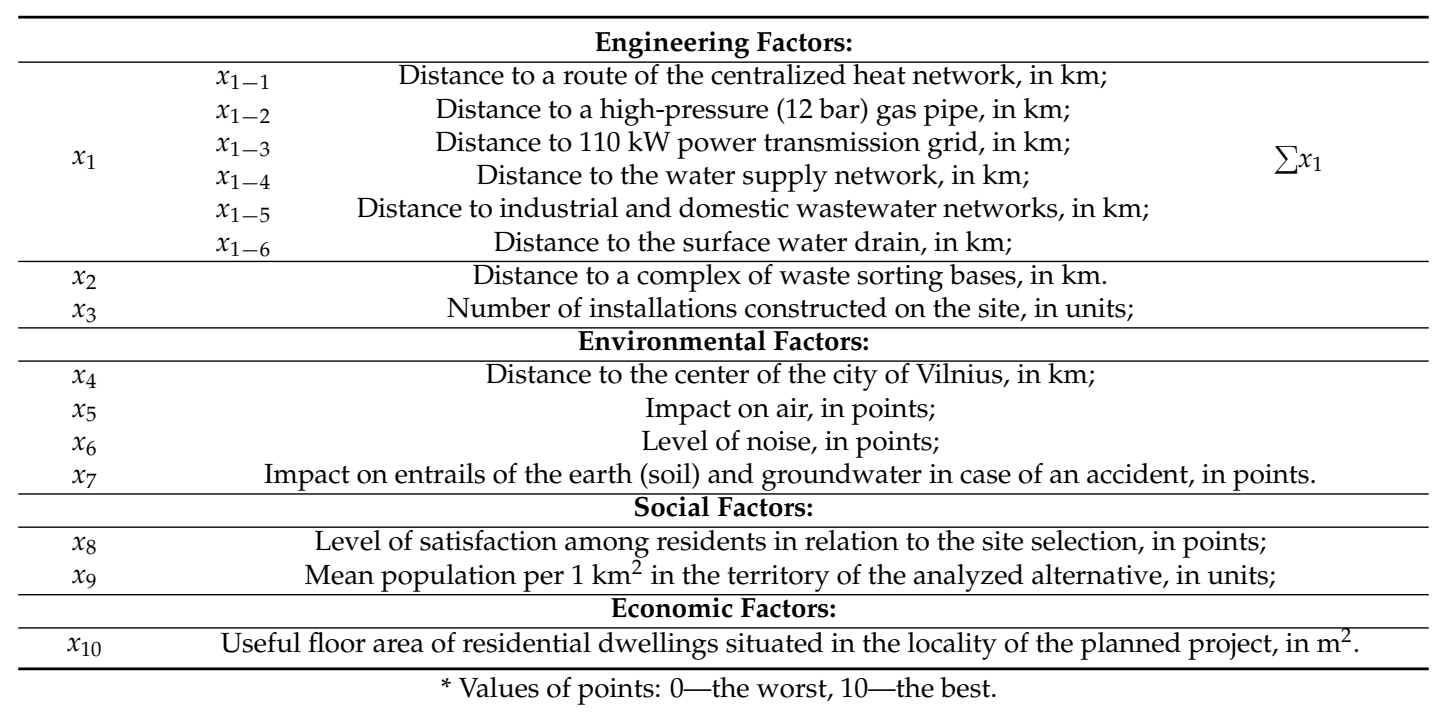


The number of installations constructed on the site $\left(x_{3}\right)$ describes a possibility to install the planned waste management/incineration installations-a waste incineration plant, and/or waste sorting plant, and/or biodegradable waste treatment plant, which require $2.5 \mathrm{ha}, 2.0$ ha, and $1.0 \mathrm{ha}$ in area, respectively—at a specific alternative site.

Environmental factors $\left(x_{4}-x_{7}\right)$ characterize the position of the incineration plant in terms of urban development and environmental effects. The distance to the center of the city $\left(x_{4}\right)$ assesses the location of the incineration plant and its possible impact on urban architecture, as a city center and surrounding quarters usually have a culturally-distinct style of architecture. Thus, such planned facilities should be kept away from culturally-important sites and located further away from residential areas. Such conclusions are determined by the power production technology, which may inconvenience residents of adjacent areas by noise, odors or aesthetics of the view.

The effect on air $\left(x_{5}\right)$, soil $\left(x_{6}\right)$, and the level of noise $\left(x_{7}\right)$ determine the impact of the waste incineration plant on the surrounding environment. The effect on air and soil results from warehousing of waste and byproducts that emerge either naturally or during the process of incineration; meanwhile, the level of noise is due to the intensified flow of transport to the plant. The intensified flow of transport results from delivery of waste from the entire Vilnius County.

Social factors of the level of satisfaction among residents $\left(x_{8}\right)$ and the mean population per $1 \mathrm{~km}^{2}$ in the territory of the analyzed alternative $\left(x_{9}\right)$ for the construction of the waste incineration plant consider the number of residents living next to the power production plant. Appropriate implementation of technological solutions during the construction of the waste incineration plant will prevent harmful effects and unpleasant odors during the exploitation of the plant. However, the negative stance of the public can bring the project implementation plans to a standstill. Assessment of the project from the point of view of public needs shows that the site of the project implementation should be chosen in the least densely populated territories. Assessment of the project on the level of the state or a private investor demonstrates that it is rational to construct the power production plant in densely populated areas to ensure the demand.

The economic factor regarding the useful floor area of residential dwellings situated in the locality of the planned project $\left(x_{10}\right)$ determines the floor area of buildings to be supplied with energy from the future power production plant. This factor is useful from the social point of view as well as in terms of the plant design: the knowledge of the useful floor area of buildings facilitates the planning of the plant capacity required to supply the power to all accessible consumers.

Table 3. The indicators of waste incineration plant site alternatives.

\begin{tabular}{|c|c|c|c|c|c|c|c|c|}
\hline \multirow{2}{*}{ Criteria } & \multirow{2}{*}{ Optimum } & \multicolumn{7}{|c|}{ Alternatives } \\
\hline & & $A_{1}$ & $A_{2}$ & $A_{3}$ & $A_{4}$ & $A_{5}$ & $A_{6}$ & $A_{7}$ \\
\hline \multirow{7}{*}{$x_{1}$} & \multirow{6}{*}{$\min$} & 1.50 & 3.50 & 0.80 & 4.80 & 5.50 & 0.60 & 0.30 \\
\hline & & 0.60 & 1.20 & 0.50 & 1.20 & 1.00 & 0.70 & 0.40 \\
\hline & & 2.50 & 4.50 & 3.00 & 1.60 & 1.60 & 2.00 & 2.00 \\
\hline & & 1.37 & 0.50 & 0.10 & 2.00 & 0.30 & 0.60 & 0.60 \\
\hline & & 1.25 & 0.50 & 0.10 & 0.50 & 0.50 & 0.60 & 0.50 \\
\hline & & 1.31 & 1.00 & 2.90 & 1.50 & 0.50 & 0.50 & 0.50 \\
\hline & $\sum x_{1}$ & 8.53 & 11.20 & 7.40 & 11.60 & 9.40 & 5.00 & 4.30 \\
\hline$x_{2}$ & $\min$ & 1.5 & 14.5 & 13.5 & 6.2 & 13.1 & 15 & 14.5 \\
\hline$x_{3}$ & $\max$ & 3 & 3 & 1 & 1 & 3 & 2 & 1 \\
\hline$x_{4}$ & $\max$ & 9.26 & 8.64 & 6.44 & 11.19 & 5.9 & 6.09 & 5.72 \\
\hline$x_{5}$ & $\max$ & 4 & 5 & 5 & 8 & 5 & 2 & 2 \\
\hline$x_{6}$ & $\max$ & 6 & 6 & 5 & 8 & 5 & 3 & 2 \\
\hline$x_{7}$ & $\max$ & 8 & 6 & 6 & 4 & 6 & 4 & 4 \\
\hline$x_{8}$ & $\max$ & 10 & 9 & 6 & 10 & 8 & 2 & 1 \\
\hline$x_{9}$ & $\min$ & 3188.6 & 497.5 & 2484 & 2676.5 & 3291 & 6490 & 5946.7 \\
\hline$x_{10}$ & $\max$ & 55,269 & 9327 & 50,798 & 56,206 & 66,807 & 13,2136 & 123,314 \\
\hline
\end{tabular}


Considering the assessed factors, alternative sites for the waste incineration plant are provided with calculated and assessed design values (Table 3).

Selecting the site for the waste incineration plant, which would be based on principles of sustainable development, it is important to carefully, minutely, responsibly, and purposefully choose alternatives, as well as evaluate the selected qualitative and quantitative indicators. Once the design values are determined for the existing factors, alternatives are evaluated using the new WASPAS-SVNS method.

\section{Sustainable Assessment of Waste Incineration Plant Construction Site Alternatives by MCDM}

\subsection{An Extension of the WASPAS Method with Single-Valued Neutrosophic Set (WASPAS-SVNS)}

Originally, a weighted aggregated sum product assessment (WASPAS) approach for the solution of the multicriteria decision-making problems has been proposed by Zavadskas et al. [28]. The proposed extension of this method, namely WASPAS-SVNS, is developed applying the framework of the single-valued neutrosophic set. The algebra of the single-valued neutrosophic set is presented in the section of the supplementary materials. The proposed approach for the solution of the formulated multiciteria decision-making problem can be outlined as follows.

Step 1. In this step, the evaluations concerning the ratings of the alternatives with respect to the attributes and the attribute weights are presented. It can be expressed by $x_{i j}, i=1,2, \ldots, m ; j=1,2, \ldots, n$, which is the aggregated experts evaluation of the $i^{\text {th }}$ alternative by the $j^{\text {th }}$ criterion. Thus, the aggregated decision matrix can be constructed:

$$
X=\left[\begin{array}{cccc}
x_{11} & x_{12} & \cdots & x_{1 n} \\
x_{21} & x_{22} & \cdots & x_{2 n} \\
\vdots & \vdots & \ddots & \vdots \\
x_{m 1} & x_{m 2} & \cdots & x_{m n}
\end{array}\right]
$$

Step 2. Normalization of the decision $X$ is performed applying vector normalization approach applying division by the norm as follows:

$$
\tilde{x}_{i j}=\frac{x_{i j}}{\sqrt{\sum_{i=1}^{m}\left(x_{i j}\right)^{2}}}
$$

In fact, this normalization technique differs from the normalization approach applied in the crisp WASPAS method. This change is necessary in order to take into account the specific computational aspects of the neutrosophic algebra.

Step 3. Neutrosophication of the normalizated aggregated decision matrix $\tilde{X}$ and the aggregated weight vector $w$ is performed. In the neutrosophication step we perform conversion of all crisp initial information into the single valued neutrosophic set. In this step, the neutrosophic aggregated decision matrix $\tilde{X}^{n}$ is determined. For this purpose we apply relationships between normalized terms of the alternatives and single-valued neutrosophic numbers. This evaluation is expressed in linguistic terms presented in the Table 4. 
Table 4. Neutrosophic conversion terms to rate importance of the alternatives.

\begin{tabular}{cc}
\hline Crisp Normalized Terms & Single-Valued Neutrosophic Numbers \\
\hline Extremely good $(\mathrm{EG}) / 1.0$ & $(1.00,0.00,0.00)$ \\
Very very good $(\mathrm{VVG}) / 0.9$ & $(0.90,0.10,0.10)$ \\
Very good $(\mathrm{VG}) / 0.8$ & $(0.80,0.15,0.20)$ \\
Good $(\mathrm{G}) / 0.7$ & $(0.70,0.25,0.30)$ \\
Medium good $(\mathrm{MG}) / 0.6$ & $(0.60,0.35,0.40)$ \\
Medium $(\mathrm{M}) / 0.5$ & $(0.50,0.50,0.50)$ \\
Medium bad (MB)/0.4 & $(0.40,0.65,0.60)$ \\
Bad $(\mathrm{B}) / 0.3$ & $(0.30,0.75,0.70)$ \\
Very bad $(\mathrm{VB}) / 0.2$ & $(0.20,0.85,0.80)$ \\
Very very bad (VVB) $/ 0.1$ & $(0.10,0.90,0.90)$ \\
Extremely bad $(\mathrm{EB}) / 0.0$ & $(0.00,1.00,1.00)$ \\
\hline
\end{tabular}

Step 4. Following the WASPAS-SVNS approach, the sum of the total relative importance of the alternative $i$ is calculated by the following equation:

$$
\widetilde{Q}_{i}^{(1)}=\sum_{j=1}^{L_{\max }} \widetilde{x}_{+i j}^{n} \cdot w_{+j}^{n}+\left(\sum_{j=1}^{L_{\min }} \widetilde{x}_{-i j}^{n} \cdot w_{-j}^{n}\right)^{c}
$$

where $\tilde{x}_{+i j}^{n}$ and $w_{+j}^{n}$ values correspond to the criteria to be maximized and $\tilde{x}_{-i j}^{n}$ and $w_{-j}^{n}$ values correspond to the criteria to be minimized. The second term of the summation consists of the complementary neutrosophic numbers, which are determined by Equation (S6).

Step.5. The second criteria of the WASPAS-SVNS methodology is determined by applying the framework of the product total relative importance of the alternative $i$ and is calculated by the following equation:

$$
\widetilde{Q}_{i}^{(2)}=\prod_{j=1}^{L_{\max }}\left(\widetilde{x}_{+i j}^{n}\right)^{w_{+j}^{n}} \cdot\left(\prod_{j=1}^{L_{\min }}\left(\widetilde{x}_{-i j}^{n}\right)^{w_{-j}^{n}}\right)^{c}
$$

The description of the terms of this equation corresponds to the definition presented at the previous step.

Step 6. A joint generalized criteria for the ranking alternatives by the proposed WASPAS-SVNS approach is determined as follows:

$$
\widetilde{Q}_{i}=0.5 \widetilde{Q}_{i}^{(1)}+0.5 \widetilde{Q}_{i}^{(2)}
$$

Step 7. In the last step, the score function $S\left(\widetilde{Q}_{i}\right)$ is determined for $i=1,2, \ldots, m$ applying Equation (S7) and the final rankings of the alternatives are calculated considering the descending order of the $\widetilde{Q}_{i}, i=1,2, \ldots, m$.

\subsection{Numerical Example}

The numerical illustration of the proposed MCDM approach, namely WASPAS-SVNS, for the solution of the considered problem is given below. The aggregated decision matrix after normalization and neutrosophication steps is presented in the Table 5.

The numerical results, representing the application of the steps $4-7$, are shown in Table 6 . The rankings of the alternatives represented in Table 6 are calculated by applying the score functions of WASPAS-SVNS (Equation (S7)). It can be concluded that the most preferred alternative is $A_{1}$. If analysis of the aggregated decision matrix is performed, it is not difficult to observe that alternative $A_{1}$ possesses the best results for $\mathrm{C}_{2}, \mathrm{C}_{3}, \mathrm{C}_{7}, \mathrm{C}_{8}$, and reasonably good results for $\mathrm{C}_{4}, \mathrm{C}_{6}$. Comparing $A_{1}$ and $A_{3}$ (they are the first and the second ones in the ranking queue) we state that the alternative $A_{1}$ is better for the criteria $\mathrm{C}_{2}, \mathrm{C}_{3}, \mathrm{C}_{4}, \mathrm{C}_{6}, \mathrm{C}_{7}, \mathrm{C}_{8}$, and $\mathrm{C}_{10}$. 
For the sake of the comparison the considered problem has been solved applying different MCDM approaches: crisp WASPAS and COPRAS methods and the fuzzy ARAS-F approach [30]. The results of the application of the original WASPAS method under the crisp information representation environment are presented in Table 7.

Table 5. The aggregated decision matrix $\tilde{X}^{n}$ after the neutrosophication step.

\begin{tabular}{|c|c|c|c|c|c|c|c|}
\hline \multirow{2}{*}{ Criteria } & \multicolumn{7}{|c|}{ Alternatives } \\
\hline & I & II & III & IV & $\mathbf{V}$ & VI & VII \\
\hline $\mathrm{C}_{1} \min$ & $\begin{array}{c}(0.3743, \\
0.6757, \\
0.6257)\end{array}$ & $\begin{array}{c}(0.4914 \\
0.5128 \\
0.5086)\end{array}$ & $\begin{array}{l}(0.3247, \\
0.7253, \\
0.6753)\end{array}$ & $\begin{array}{c}(0.5090 \\
0.4865 \\
0.4910)\end{array}$ & $\begin{array}{c}(0.4125 \\
0.6313 \\
0.5875)\end{array}$ & $\begin{array}{c}(0.2194 \\
0.8306 \\
0.7806)\end{array}$ & $\begin{array}{c}(0.1887, \\
0.8557, \\
0.8113)\end{array}$ \\
\hline $\mathrm{C}_{2} \min$ & $\begin{array}{l}0.0465, \\
0.9535 \\
0.9535)\end{array}$ & $\begin{array}{c}0.4496 \\
0.5756, \\
0.5504)\end{array}$ & $\begin{array}{c}0.4186, \\
0.6221, \\
0.5814)\end{array}$ & $\begin{array}{c}0.1922, \\
0.8539, \\
0.8078)\end{array}$ & $\begin{array}{c}0.4062, \\
0.6407, \\
0.5938)\end{array}$ & $\begin{array}{l}(0.4651 \\
0.5523 \\
0.5349)\end{array}$ & $\begin{array}{c}(0.4496, \\
0.5756, \\
0 . .5504)\end{array}$ \\
\hline $\mathrm{C}_{3} \max$ & $\begin{array}{l}(0.5145, \\
0.4783 \\
0.4855)\end{array}$ & $\begin{array}{l}(0.5145 \\
0.4783 \\
0.4855)\end{array}$ & $\begin{array}{l}(0.1715, \\
0.8643, \\
0.8285)\end{array}$ & $\begin{array}{l}(0.1715 \\
0.8643 \\
0.8285)\end{array}$ & $\begin{array}{c}(0.5145 \\
0.4783 \\
0.4855)\end{array}$ & $\begin{array}{c}(0.3430 \\
0.7070 \\
0.6570)\end{array}$ & $\begin{array}{c}0.1715, \\
0.8643, \\
0.8285)\end{array}$ \\
\hline $\mathrm{C}_{4} \max$ & $\begin{array}{c}0.4457, \\
0.5815 \\
0.5543)\end{array}$ & $\begin{array}{c}(0.4158, \\
0.6262, \\
0.5842)\end{array}$ & $\begin{array}{c}(0.3100 \\
0.7400 \\
0.6900)\end{array}$ & $\begin{array}{l}(0.5386 \\
0.4422 \\
0.4614)\end{array}$ & $\begin{array}{c}(0.2840 \\
0.7660 \\
0.7160)\end{array}$ & $\begin{array}{l}(0.2931 \\
0.7569 \\
0.7069)\end{array}$ & $\begin{array}{c}(0.2753, \\
0.7747, \\
0.7247)\end{array}$ \\
\hline $\mathrm{C}_{5} \max$ & $\begin{array}{c}0.3133, \\
0.7367, \\
0.6867)\end{array}$ & $\begin{array}{c}(0.3916, \\
0.6584, \\
0.6084)\end{array}$ & $\begin{array}{c}0.3916, \\
0.6584, \\
0.6084)\end{array}$ & $\begin{array}{c}(0.6266, \\
0.3234, \\
0.3734)\end{array}$ & $\begin{array}{c}(0.3916, \\
0.6584, \\
0.6084)\end{array}$ & $\begin{array}{c}(0.1567, \\
0.8717 \\
0.8433)\end{array}$ & $\begin{array}{c}0.1567, \\
0.8717, \\
0.8433)\end{array}$ \\
\hline $\mathrm{C}_{6} \max$ & $\begin{array}{c}(0.4253, \\
0.6120 \\
0.5747)\end{array}$ & $\begin{array}{c}(0.4253, \\
0.6120 \\
0.5747)\end{array}$ & $\begin{array}{c}(0.3544, \\
0.6956, \\
0.6456)\end{array}$ & $\begin{array}{l}(0.5671 \\
0.3993 \\
0.4329)\end{array}$ & $\begin{array}{c}(0.3544, \\
0.6956, \\
0.6456)\end{array}$ & $\begin{array}{c}(0.2127 \\
0.8373 \\
0.7873)\end{array}$ & $\begin{array}{c}(0.1418, \\
0.8791 \\
0.8582)\end{array}$ \\
\hline $\mathrm{C}_{7} \max$ & $\begin{array}{c}(0.5394 \\
0.4410 \\
0.4606)\end{array}$ & $\begin{array}{c}(0.4045, \\
0.6432, \\
0.5955)\end{array}$ & $\begin{array}{c}0.4045, \\
0.6432, \\
0.5955)\end{array}$ & $\begin{array}{l}0.2697 \\
0.7803 \\
0.7303)\end{array}$ & $\begin{array}{c}0.4045, \\
0.6432, \\
0.5955)\end{array}$ & $\begin{array}{l}0.2697 \\
0.7803 \\
0.7303)\end{array}$ & $\begin{array}{c}0.2697, \\
0.7803, \\
0.7303)\end{array}$ \\
\hline $\mathrm{C}_{8} \max$ & $\begin{array}{c}0.5090 \\
0.4865 \\
0.4910)\end{array}$ & $\begin{array}{c}0.4581 \\
0.5629 \\
0.5419)\end{array}$ & $\begin{array}{c}(0.3054, \\
0.7446, \\
0.6946)\end{array}$ & $\begin{array}{l}0.5090 \\
0.4865 \\
0.4910)\end{array}$ & $\begin{array}{c}0.4072, \\
0.6392, \\
0.5928)\end{array}$ & $\begin{array}{c}0.1018, \\
0.8991, \\
0.8982)\end{array}$ & $\begin{array}{l}0.0509, \\
0.9491, \\
0.9491)\end{array}$ \\
\hline $\mathrm{C}_{9} \min$ & $\begin{array}{c}0.3012, \\
0.7488, \\
0.6988)\end{array}$ & $\begin{array}{c}(0.0470, \\
0.9530 \\
0.9530)\end{array}$ & $\begin{array}{l}0.2347, \\
0.8153, \\
0.7653)\end{array}$ & $\begin{array}{l}0.2528 \\
0.7972 \\
0.7472)\end{array}$ & $\begin{array}{c}0.3109, \\
0.7391, \\
0.6891)\end{array}$ & $\begin{array}{l}0.6131 \\
0.3369 \\
0.3869)\end{array}$ & $\begin{array}{c}0.5618, \\
0.4074, \\
0.4382)\end{array}$ \\
\hline $\mathrm{C}_{10} \max$ & $\begin{array}{c}(0.2577, \\
0.7923, \\
0.7423)\end{array}$ & $\begin{array}{c}(0.0435, \\
0.9565, \\
0.9565)\end{array}$ & $\begin{array}{c}(0.2368, \\
0.8132, \\
0.7632)\end{array}$ & $\begin{array}{c}(0.2620 \\
0.7880 \\
0.7380)\end{array}$ & $\begin{array}{c}(0.3115 \\
0.7385 \\
0.6885)\end{array}$ & $\begin{array}{c}(0.6160 \\
0.3340 \\
0.3840)\end{array}$ & $\begin{array}{c}(0.5749, \\
0.3877, \\
0.4251)\end{array}$ \\
\hline
\end{tabular}

Table 6. Numerical results of WASPAS-SVNS.

\begin{tabular}{cccccccc}
\hline & \multicolumn{7}{c}{ Alternatives } \\
\cline { 2 - 8 } & I & II & III & IV & V & VI & VII \\
\hline \multirow{2}{*}{$\widetilde{Q}^{(1)}$} & $(0.9603$, & $(0.9423$, & $(0.9508$, & $(0.9416$, & $(0.9431$, & $(0.9186$, & $(0.9239$, \\
& 0.0375, & 0.0603, & 0.0491, & 0.0549, & 0.0570, & 0.0910, & 0.0821, \\
& $0.449)$ & $0.0619)$ & $0.0594)$ & $0,0581)$ & $0.0666)$ & $0.0894)$ & $0.0836)$ \\
\hline \multirow{2}{*}{$\widetilde{Q}^{(2)}$} & $(0.1108$, & $(0.0923$, & $(0.0865$, & $(0.1081$, & $(0.1006$, & $(0.0591$, & $(0.0482$, \\
& 0.8959, & 0.9157, & 0.9260, & 0.8964, & 0.9114, & 0.9486, & 0.9577, \\
& $0.8892)$ & $0.9077)$ & $0.9135)$ & $0.8919)$ & $0.8994)$ & $0.9409)$ & $0.9518)$ \\
\hline \multirow{2}{*}{$\widetilde{Q}$} & $(0.6500$, & $(0.6029$, & $(0.6198$, & $(0.6062$, & $(0.6071$, & $(0.5485$, & $(0.5539$, \\
& 0.3459, & 0.4049, & 0.3837, & 0.3879, & 0.3967, & 0.4695, & 0.4582, \\
\hline$S(\widetilde{Q})$ & $0.3441)$ & $0.4025)$ & $0.3800)$ & $0.3865)$ & $0.3931)$ & $0.4669)$ & $0.4563)$ \\
\hline Rank & 0.6535 & 0.5976 & 0.6181 & 0.6110 & 0.6052 & 0.5356 & 0.5453 \\
\hline & 1 & 5 & 2 & 3 & 4 & 7 & 6 \\
\hline
\end{tabular}


Table 7. Numerical results of the original crisp WASPAS method.

\begin{tabular}{cccccccc}
\hline & \multicolumn{7}{c}{ Alternatives } \\
\cline { 2 - 8 } & I & II & III & IV & V & VI & VII \\
\hline$\widetilde{Q}^{(1)}$ & 0.7550 & 0.7023 & 0.5816 & 0.7025 & 0.6416 & 0.4625 & 0.4238 \\
$\widetilde{Q}^{(2)}$ & 0.6578 & 0.5780 & 0.5077 & 0.5980 & 0.5578 & 0.3411 & 0.2874 \\
$\widetilde{Q}$ & 0.7064 & 0.6402 & 0.5446 & 0.6502 & 0.5997 & 0.4028 & 0.3556 \\
Rank & 1 & 3 & 5 & 2 & 4 & 6 & 7 \\
\hline
\end{tabular}

The final rankings of the alternatives obtained by different MCDM approaches are presented in Table 8. It is not difficult to observe that different crisp methods, such as WASPAS and COPRAS provided exactly the same results. On the other hand, the fuzzy approach ARAS-F and the proposed method WASPAS-SVNS took into account the different components of the uncertainty of the initial information so the final ranking of the alternatives slightly differs from the results obtained by crisp methods. However, the best alternative is the same applying different MCDM approaches and this fact supports the conclusion that the first alternative is the best candidate for the waste incineration plant construction site.

Table 8. Comparison of the results obtained by solution with different MCDM approaches.

\begin{tabular}{cccccccc}
\hline \multirow{2}{*}{ Method } & \multicolumn{7}{c}{ Alternatives } \\
\cline { 2 - 8 } & I & II & III & IV & V & VI & VII \\
\hline Original crisp WASPAS & 1 & 3 & 5 & 2 & 4 & 6 & 7 \\
Proposed WASPAS-SVNS & 1 & 5 & 2 & 3 & 4 & 7 & 6 \\
ARAS-F & 1 & 2 & 5 & 3 & 4 & 6 & 7 \\
COPRAS & 1 & 3 & 5 & 2 & 4 & 6 & 7 \\
\hline
\end{tabular}

On the other hand, it is necessary to point out that migration of the alternatives obtained by different MCDM methods do not exceed the grouping of the alternatives in three localized zones: two zones are situated in territories allocated for the industrial development of the city $\left(A_{4}, A_{1}\right.$ and $\left.A_{2}, A_{3}, A_{5}\right)$ and one zone in densely populated parts of the city $\left(A_{6}, A_{7}\right)$.

\section{Conclusions}

Determining the site for a waste incineration plant is a complicated process that has many social, economic, political, and technological factors. Implementation of such projects involves many different stakeholder groups whose needs must be considered to achieve success. In the search for the best solutions it is, therefore, rational to draw on methods developed by scientists that can encompass and assess large quantities of information.

Seven alternatives were analyzed to select the site of the waste incineration plant in the city of Vilnius. Alternatives are distributed in zones intended for the industrial development of the city and densely populated areas. According to the assessment of the location of alternatives in the territory of the city, the analyzed rational sites for the waste incineration plant comprise three localized zones. Two zones are situated in territories allocated for the industrial development of the city $\left(A_{4}, A_{1}\right.$ and $\left.A_{2}, A_{3}, A_{5}\right)$ and one zone in densely populated parts of the city $\left(A_{6}, A_{7}\right)$.

The zone with alternatives $A_{2}, A_{3}$, and $A_{5}$ have challenges related to the connection to engineering communications and construction of access roads. The airport of Vilnius is the key challenge for the design of the flue-gas stack of the incineration plant in this particular zone. Thus, from the point of view of rational development, requirements of stakeholder groups can be satisfied by choosing the alternative $a_{1}$, which is selected based on calculated results. This site is technologically fit for the construction of waste incineration, waste sorting, and biodegradable waste treatment plants. 
Within the MCDM framework we have developed a new extension of the original crisp WASPAS method. The proposed new extension, namely WASPAS-SVNS, applies the framework of the single-valued neutrosophic set. Comparison of the results obtained by other MCDM approaches has been performed. Based on calculated results, the most appropriate site for the construction of the plant for incineration of non-hazardous wastes in the city of Vilnius is Gariūnai District. Considering the results, it can be concluded that this territory is suitable for the implementation of the project for the construction of a waste incineration plant.

Multiple criteria methods facilitate the best decision-making and, therefore, they should be used to ensure balanced waste management. Based on principles of sustainable development, a waste management system helps to balance regional waste flows and their further appropriate utilization.

Author Contributions: Edmundas Kazimieras Zavadskas discussed the main idea of the research. Romualdas Bausys and Marius Lazauskas dealt with the main research, analyzed the obtained results and performed the development of the paper. All authors have read and approved the final manuscript.

Conflicts of Interest: The authors declare no conflict of interest.

\section{Appendix}

\section{Neutrosophic Sets}

Smarandache [32] originally proposed the concept of a neutrosophic set from philosophical point of view and we present a brief review of general concepts of neutrosophic set.

Definition 1. Let $X$ be space of the objects and $x \in X$. A neutrosophic set $A$ in $X$ is defined by three functions: truth-membership function $T_{A}(x)$, an indeterminacy-membership function $I_{A}(x)$ and falsity-membership function $F_{A}(x)$. These functions $T_{A}(x), I_{A}(x)$ and $F_{A}(x)$ are defined on real standard or real non-standard subsets of $] 0^{-}, 1^{+}\left[\right.$. That is $\left.T_{A}(x): X \rightarrow\right] 0^{-}, 1^{+}[$, $\left.I_{A}(x): X \rightarrow\right] 0^{-}, 1^{+}\left[\right.$and $\left.F_{A}(x): X \rightarrow\right] 0^{-}, 1^{+}\left[\right.$. We have no any restriction on the sum of $T_{A}(x)$, $I_{A}(x)$ and $F_{A}(x)$, so $0^{-} \leqslant \sup T_{A}(x)+\sup I_{A}(x)+\sup F_{A}(x) \leqslant 3^{+}$.

Definition 2. A single-valued neutrosophic set (SVNS) has been defined as described in Wang et al., scientific work [38]. Let $X$ be a universal space of the objects and $x \in X$. A single-valued neutrosophic set (SVNS) $\tilde{N} \subset X$ can be expressed as

$$
\widetilde{N}=\left\{\left\langle x, T_{\widetilde{N}}(x), I_{\widetilde{N}}(x), F_{\widetilde{N}}(x)\right\rangle: x \in X\right\}
$$

where $T_{\widetilde{N}}(x): X \rightarrow[0,1], I_{\widetilde{N}}(x): X \rightarrow[0,1]$ and $F_{\widetilde{N}}(x): X \rightarrow[0,1]$ with $0 \leqslant T_{\widetilde{N}}(x)+I_{\widetilde{N}}(x)+$ $F_{\widetilde{N}}(x) \leqslant 3$ for all $x \in X$. The values $T_{\widetilde{N}}(x), I_{\widetilde{N}}(x)$ and $F_{\widetilde{N}}(x)$ correspond to truth-membership degree, the indeterminacy-membership degree and the falsity-membership degree of $x$ to $\tilde{N}$, respectively. For the case when $X$ consists of the single element, $\tilde{N}$ is called a single-valued neutrosophic number [33]. For the sake of the simplicity, a single valued neutrosophic number is expressed by $\tilde{N}_{A}=\left(t_{A}, i_{A}, f_{A}\right)$ where $t_{A}, i_{A}, f_{A} \in[0,1]$ and $0 \leqslant t_{A}+i_{A}+f_{A} \leqslant 3$.

Definition 3. If $\tilde{N}_{1}=\left(t_{1}, i_{1}, f_{1}\right)$ and $\tilde{N}_{2}=\left(t_{2}, i_{2}, f_{2}\right)$ are two single-valued neutrosophic numbers (SVNN), then the summation between $\widetilde{N}_{1}$ and $\widetilde{N}_{2}$ can be expressed as follows

$$
\tilde{N}_{1} \oplus \tilde{N}_{2}=\left(t_{1}+t_{2}-t_{1} t_{2}, i_{1} i_{2}, f_{1} f_{2}\right)
$$

Definition 4. If $\tilde{N}_{1}=\left(t_{1}, i_{1}, f_{1}\right)$ and $\tilde{N}_{2}=\left(t_{2}, i_{2}, f_{2}\right)$ are two single-valued neutrosophic numbers, then multiplication between $\widetilde{N}_{1}$ and $\tilde{N}_{2}$ can be expressed as follows

$$
\tilde{N}_{1} \otimes \tilde{N}_{2}=\left(t_{1} t_{2}, i_{1}+i_{2}-i_{1} i_{2}, f_{1}+f_{2}-f_{1} f_{2}\right)
$$


Definition 5. If $\widetilde{N}_{1}=\left(t_{1}, i_{1}, f_{1}\right)$ is a single-valued neutrosophic number and $\lambda \in \Re$ is an arbitrary positive real number then

$$
\lambda \widetilde{N}_{1}=\left(1-\left(1-t_{1}\right)^{\lambda}, i_{1}^{\lambda}, f_{1}^{\lambda}\right), \lambda>0
$$

Definition 6. If $\tilde{N}_{1}=\left(t_{1}, i_{1}, f_{1}\right)$ is a single-valued neutrosophic number and $\lambda \in \Re$ is an arbitrary positive real number then

$$
\tilde{N}_{1}^{\lambda}=\left(t_{1}^{\lambda}, 1-\left(1-i_{1}\right)^{\lambda}, 1-\left(1-f_{1}\right)^{\lambda}\right), \lambda>0
$$

Definition 7. If $\tilde{N}_{1}=\left(t_{1}, i_{1}, f_{1}\right)$ is a single-valued neutrosophic number then the complementary component of this single valued neutrosophic number is determined as follows

$$
\tilde{N}_{1}^{c}=\left(f_{1}, 1-i_{1}, t_{1}\right)
$$

Definition 8. If $\tilde{N}_{A}=\left(t_{A}, i_{A}, f_{A}\right)$ is a single-valued neutrosophic number, a score function is mapped $\tilde{N}_{A}$ into the single crisp output $S\left(\tilde{N}_{A}\right)$ as follows

$$
S\left(\tilde{N}_{A}\right)=\frac{3+t_{A}-2 i_{A}-f_{A}}{4}
$$

where $S\left(\tilde{N}_{A}\right) \in[0,1]$. This score function is the modification of the score function proposed by Sahin and Kucuk [39] and allows us to have the results in the same interval as we deal with single valued neutrosophic numbers.

Definition 9. Let $\tilde{N}_{1}$ and $\tilde{N}_{2}$ be any two SVNNs. Therefore, if $S\left(\widetilde{N}_{1}\right)<S\left(\widetilde{N}_{2}\right)$ then $\tilde{N}_{1}$ is smaller than $\tilde{N}_{2}, \tilde{N}_{1}<\tilde{N}_{2}$.

\section{References}

1. Towards a Circular Economy: A Zero Waste Programme for Europe. Available online: http:/ /ec.europa.eu/ environment/circular-economy/pdf/circular-economy-communication.pdf (accessed on 24 November 2015).

2. O'Connor, G.A.; Elliott, H.A.; Basta, N.T.; Bastian, R.K.; Pierzynski, G.M.; Sims, R.C.; Smith, J.E., Jr. Sustainable land application: An overview. J. Environ. Qual. 2005, 34, 7-17. [CrossRef] [PubMed]

3. Yang, W.; Yang, Z.F. Evaluation of Sustainable Environmental Flows Based on the Valuation of Ecosystem Services: A Case Study for the Baiyangdian Wetland, China. J. Environ. Inf. 2014, 24, 90-100. [CrossRef]

4. Ma, Z.Z.; Wang, Z.Z.; Xia, T.; Gippel, C.J.; Speed, R. Hydrograph-Based Hydrologic Alteration Assessment and Its Application to the Yellow River. J. Environ. Inf. 2014, 23, 1-13. [CrossRef]

5. Ni, J.R.; Wu, A.; Li, T.H.; Yue, Y.; Borthwick, A.G.L. Efficient Soil Loss Assessment for Large Basins Using Smart Coded Polygons. J. Environ. Inf. 2014, 23, 47-57. [CrossRef]

6. Cherubini, F.; Bargigli, S.; Ulgiati, S. Life cycle assessment (LCA) of waste management strategies: Landfilling, sorting plant and incineration. Energy 2009, 12, 2116-2123. [CrossRef]

7. Marchettini, N.; Ridolfi, R.; Rustici, M. An environmental analysis for comparing waste management options and strategies. Waste Manag. 2007, 27, 562-571. [CrossRef] [PubMed]

8. Margallo, M.; Taddei, M.B.M.; Hernández-Pellón, A.; Aldaco, R.; Irabien, Á. Environmental sustainability assessment of the management of municipal solid waste incineration residues: A review of the current situation. Clean Technol. Environ. Policy 2015. [CrossRef]

9. Brunner, P.H.; Rechberger, H. Waste to energy-Key element for sustainable waste management. Waste Manag. 2015, 37, 3-12. [CrossRef] [PubMed]

10. Margallo, M.; Dominguez-Ramos, A.; Aldaco, R.; Bala, A.; Fullana, P.; Irabien, A. Environmental sustainability assessment in the process industry: A case study of waste-to-energy plants in Spain. Resources. Conserv. Recycl. 2014, 93, 144-155. [CrossRef] 
11. Wilson, D.C.; Rodic, L.; Cowing, M.J.; Velis, C.A.; Whiteman, A.D.; Scheinberg, A.; Vilches, R.; Masterson, D.; Stretz, J.; Oelz, B. "Wasteaware" benchmark indicators for integrated sustainable waste management in cities. Waste Manag. 2015, 35, 329-342. [CrossRef] [PubMed]

12. Corvellec, H.; Campos, M.J.Z.; Zapata, P. Infrastructures, lock-in, and sustainable urban development: The case of waste incineration in the Göteborg Metropolitan Area. J. Clean. Prod. 2013, 50, 32-39. [CrossRef]

13. Sharifi, M.; Hadidi, M.; Vessali, E.; Mosstafakhani, P.; Taheri, K.; Shahoie, S.; Khodamoradpour, M. Integrating multi-criteria decision analysis for a GIS-based hazardous waste landfill sitting in Kurdistan Province, western Iran. Waste Manag. 2009, 29, 2740-2758. [CrossRef] [PubMed]

14. Manowong, E. Investigating factors influencing construction waste management efforts in developing countries: An experience from Thailand. Waste. Manag. Res. 2012, 30, 56-71. [CrossRef] [PubMed]

15. Costi, P.; Minciardi, R.; Robba, M.; Rovatti, M.; Sacile, R. An environmentally sustainable decision model for urban solid waste management. Waste Manag. 2004, 24, 277-295. [CrossRef]

16. Den Boer, J.; den Boer, E.; Jager, J. LCA-IWM: A decision support tool for sustainability assessment of waste management systems. Waste Manag. 2007, 27, 1032-1045. [CrossRef] [PubMed]

17. Kiker, G.A.; Bridges, T.S.; Varghese, A.; Seager, T.P.; Linkovj, I. Application of multicriteria decision analysis in environmental decision making. Integr. Environ. Assess. Manag. 2005, 1, 95-108. [CrossRef] [PubMed]

18. Zavadskas, E.K.; Turskis, Z.; Kildienè, S. State of art surveys of overviews on MCDM/MADM methods. Technol. Econ. Dev. Econ. 2014, 20, 165-179. [CrossRef]

19. Mardani, A.; Jusoh, A.; Nor, K.M.D.; Khalifah, Z.; Zakwan, N.; Valipour, A. Multiple criteria decision-making techniques and their applications-A review of the literature from 2000 to 2014. Econ. Res. Ekon. Istraž. 2015, 28, 516-571. [CrossRef]

20. Kahraman, C.; Onar, S.C.; Oztaysi, B. Fuzzy Multicriteria Decision-Making: A Literature Review. Int. J. Comput. Intell. Syst. 2015, 8, 637-666. [CrossRef]

21. Streimikiene, D.; Balezentis, T.; Krisciukaitienè, I.; Balezentis, A. Prioritizing sustainable electricity production technologies: MCDM approach. Renew. Sustain. Energy Rev. 2012, 16, 3302-3311. [CrossRef]

22. Kabir, G.; Sadiq, R.; Tesfamariam, S. A review of multi-criteria decision-making methods for infrastructure management. Struct. Infrastruct. Eng.: Maint. Manag. Life Cycle Des. Perform. 2014, 10, 1176-1210. [CrossRef]

23. Mulliner, E.; Smallbone, K.; Maliene, V. An assessment of sustainable housing affordability using a multiple criteria decision making method. Omega 2013, 41, 270-279. [CrossRef]

24. Zhao, H.; Guo, S. Selecting Green Supplier of Thermal Power Equipment by Using a Hybrid MCDM Method for Sustainability. Sustainability 2014, 6, 217-235. [CrossRef]

25. Hashemkhani Zolfani, S.; Saparauskas, J. New Application of SWARA Method in Prioritizing Sustainability Assessment Indicators of Energy System. Inzinerine Ekon.-Eng. Econ. 2013, 24, 408-414.

26. Yazdani-Chamzini, A.; Shariati, S.; Yakhchali, A.H.; Zavadskas, E.K. Proposing a new methodology for prioritising the investment strategies in the private sector of Iran. Econ. Res.-Ekon. Istraž. 2014, 27, 320-345. [CrossRef]

27. Rikhtegar, N.; Mansouri, N.; Oroumieh, A.A.; Yazdani-Chamzini, A.; Zavadskas, E.K.; Kildienè, S. Environmental impact assessment based on group decision-making methods in mining projects. Econ. Res. Ekon. Istraž. 2014, 27, 378-392. [CrossRef]

28. Zavadskas, E.K.; Antuchevičienė, J.; Hajiagha, S.H.R.; Hashemi, S.S. Extension of weighted aggregated sum product assessment with interval-valued intuitionistic fuzzy numbers (WASPAS-IVIF). Appl. Soft Comput. 2014, 24, 1013-1021. [CrossRef]

29. Bausys, R.; Zavadskas, E.K.; Kaklauskas, A. Application of neutrosophic set to multicriteria decision making by COPRAS. Econ. Comput. Econ. Cybern. Stud. Res. 2015, 49, 91-106.

30. Turskis, Z.; Lazauskas, M.; Zavadskas, E.K. Fuzzy multiple criteria assessment of construction site alternatives for non-hazardous waste incineration plant in Vilnius city, applying ARAS-F and AHP methods. J. Environ. Eng. Landsc. Manag. 2012, 2, 110-120. [CrossRef]

31. Zavadskas, E.K.; Antuchevičienè, J.; Šaparauskas, J.; Turskis, Z. MCDM methods WASPAS and MULTIMOORA: Verification of robustness of methods when assessing alternative solutions. J. Econ. Comput. Econ. Cybern. Stud. Res. 2013, 47, 5-20.

32. Smarandache, F. A Unifying Field in Logics. Neutrosophy: Neutrosophic Probability, Set and Logic; American Research Press: Rehoboth, DE, USA, 1999. 
33. Peng, J.J.; Wang, J.Q.; Zhang, H.Y.; Chen, X.H. An outranking approach for multi-criteria decision-making problems with simplified neutrosophic sets. Appl. Soft Comput. 2014, 25, 336-346. [CrossRef]

34. Zhang, Z.; Wu, C. A Novel Method for Single-valued Neutrosophic Multi-Criteria Decision Making with Incomplete Weight Information. Neutrosophic Sets Syst. 2014, 4, 35-49.

35. UAB “VAATC" 2014 Announcement. Available online: http://www.vaatc.lt/wp-content/uploads/2014/ 05/2014-m.-UAB-VAATC-metinis-pranesimas.pdf (accessed on 24 November 2015).

36. Economic Analysis of Options for Managing Biodegradable Municipal Waste. Available online: http://ec.europa.eu/environment/waste/compost/pdf/econanalysis_finalreport.pdf (accessed on 24 November 2015).

37. The Vilnius Regional Municipal Waste Management System Development Feasibility Study. Available online: http://www.slideshare.net/VilniausSavivaldybe/atliek-tvarkymo-galimybi-studija (accessed on 24 November 2015).

38. Wang, H.; Smarandache, F.; Zhang, Y.Q.; Sunderraman, R. Single valued neutrosophic sets. Multispace Multistruct. 2010, 4, 410-413.

39. Sahin, R.; Kucuk, A. Subsethood Measure for Single Valued Neutrosophic Sets. J. Intell. Fuzzy Syst. 2014. [CrossRef]

(C) 2015 by the authors; licensee MDPI, Basel, Switzerland. This article is an open access article distributed under the terms and conditions of the Creative Commons by Attribution (CC-BY) license (http:/ / creativecommons.org/licenses/by/4.0/). 